\title{
THE PALEONTOLOGICAL SOCIETY PAPERS
}

Volume 1: Paleobiology and Biology of Corals.

Edited by G. D. Stanley, Jr., 1996, 291 pp., $\$ 20.00$

Volume 2: Learning from the Fossil Record.

Edited by J. Scotchmoor and F. K. McKinney, 1996, 329 pp., $\$ 20.00$

Volume 3: Geobiology of Echinoderms.

Edited by J. A. Waters and C. G. Maples, 1997, 355 pp., $\$ 20.00$

Volume 4: Isotope Paleobiology and Paleoecology.

Convened by R. D. Norris and R. M. Corfield, 1998, 285 pp., \$20.00

All volumes of the Paleontological Society Papers, as well as other publications listed on the back cover of this volume, are available by mail order from:

\section{Paleontological Society Special Publications \\ The Carnegie Museum of Natural History \\ 4400 Forbes Avenue \\ Pittsburgh, PA 15213-4080 \\ Contact: Ilona Weyers \\ Phone: (412) 622-1947 \\ Fax: (412) 622-8837 \\ E-Mail: weyersi@clpgh.com}

A check or institutional purchase order must accompany the order. Payment is to be made in US\$ to The Paleontological Society. Orders will be shipped $4^{\text {th }}$ class mail/surface. For destinations within North America add US $\$ 2.00$ postage per book ( $\$ 10.00$ maximum, additional books are shipped free) plus a onetime processing fee of $\$ 1.50$ per order. For orders outside North America add US $\$ 4.00$ postage per book ( $\$ 20.00$ maximum, additional books are shipped free) plus a one-time processing fee of $\$ 1.50$ per order.

Prices are effective on July 1, 1998. 


\section{PALEONTOLOGICAL SOCIETY SPECIAL PUBLICATIONS, 1980-1997}

\section{Short Course Notes:}

Mammals. Organized by P. D. Gingerich and C. E. Badgley, 1984, 234 pp., \$ 15

Mollusks. Organized by D. J. Bottjer, C. S. Hickman, and P. D. Ward, 1985, 305 pp., \$ 15

Land Plants. Organized by R. A. Gastaldo, 1986, 226 pp., \$ 15

Fossil Prokaryotes and Protists. Organized by J. H. Lipps, 1987, 303 pp., \$ 5

\section{Short Courses in Paleontology:}

Number 1: Molecular Evolution and the Fossil Record.

Organized by B. Runnegar and J. W. Schopf, 1988, 167 pp. (Out of Print)

Number 2: The Age of Dinosaurs.

Organized by K. Padian and D. J. Chure, 1989, 210 pp., \$ 15

Number 3: Arthropod Paleobiology.

Organized by D. L. Mikulic, 1990, 315 pp., \$ 15

Number 4: Analytical Paleobiology.

Organized by N. L. Gilinsky and P. W. Signor, 1991, 216 pp., \$ 20

Number 5: Trace Fossils.

Organized and edited by C. G. Maples and R. R. West, 1992, 238 pp., \$ 15

Number 6: Taphonomic Approaches to Time Resolution in Fossil Assemblages.

Organized and edited by S. M. Kidwell and A. K. Behrensmeyer, 1993, 302 pp., \$ 20

Number 7: Major Features of Vertebrate Evolution.

Organized and edited by D. R. Prothero and R. M. Schoch, 1994, 270 pp., \$ 20

Number 8: Siliceous Microfossils.

Organized by C. D. Blome, P. M. Whalen, and K. M. Reed, 1995, 185 pp., \$ 20

\section{Special Publications:}

Volume 1: The Evolution-Creation Controversy: Perspectives on Religion, Science, and Education - A Handbook. (Out of Print)

Volume 2: Paleoecology and Taphonomy of Pleistocene to Recent Intertidal Deposits, Gulf of California. Edited by K. W. Flessa, 1987, 237 pp., \$ 5

Volume 3: Methods and Applications of Plant Paleoecology.

Edited by W. A. DiMichele and S. L. Wing, 1988, 171 pp., $\$ 5$

Volume 4: Paleotechniques.

Edited by R. M. Feldmann, R. E. Chapman, and J. T. Hannibal, 1989, 358 pp., \$ 20

Volume 5: Paleocommunity Temporal Dynamics: The Long-term Development of Multispecies Assemblies. Edited by W. Miller, III, 1990, 421 pp. (Out of Print)

Volume 6: Fifth North American Paleontological Convention - Abstracts and Program. Edited by S. Lidgard and P. R. Crane, 1992, (Out of Print)

Volume 7: Dino Fest.

Edited by G. D. Rosenberg and D. L. Wolberg, 1994, 500 pp., \$ 20

Volume 8: Sixth North American Paleontological Convention Abstracts of Papers.

Edited by J. E. Repetski, Jr., 1996, 443 pp., \$ 5 